\title{
Identifying Evidence-Based Teaching Strategies that Teachers Use in Inclusive Primary Classrooms in Southern Bangladesh
}

\author{
Asim Das, PhD \\ Assistant Professor \\ Hiroshima University, Japan \\ E-mail : asimierdu@yahoo.com
}

\section{Doi:10.5901/jesr.2013.v3n7p639}

\begin{abstract}
Evidence-based teaching strategies are clearly specified teaching strategies that have been shown in controlled research to be effective in bringing about desired outcomes in a delineated population of learners. For teaching-learning process in inclusive classrooms, evidence-based teaching strategies can play a vital role for quality learning especially for the students with disabilities. Although implementation of inclusion in primary education was started in 2003 in Bangladesh, the classroom teachers are frequently struggling with the challenges in teaching-learning process in mainstream education. It is believed that teachers are not sufficiently well-prepared and supported to teach students with disabilities in their classroom. But undoubtedly, the hallmark of effective inclusion is well-trained teachers and teaching strategies that teachers use to teach students with disabilities. The present study was conducted to determine teachers' teaching strategies they practice for students with disabilities in mainstream primary classroom in some selected primary schools of Southern Bangladesh. In this study, a questionnaire focusing on 18 evidence-based teaching strategies was developed for data collection. In the results, differences were observed in the extent to which teachers used teaching-strategies in their classrooms that are evidencebased. While some teachers reported using some of the strategies most often or sometimes, others indicated less frequent use. On the basis of the findings, recommendations were made to encourage teachers in mainstream education to use evidence-based teaching strategies that facilitate the actual inclusion.
\end{abstract}

Keywords: Evidence-based Teaching Strategy, Students with Disabilities, Inclusive Classroom, Bangladesh

\section{Introduction}

Over the past two decades, there has been a common and widespread drive by international governments towards inclusion as a model for education. As such, inclusion has now become one of the most critical educational issues internationally. The basic premise underpinning inclusion is that all children regardless of ability or disability have a basic right to be educated alongside their peers in their local school. Inclusion is thus generally defined as "providing effective learning opportunities for all pupils". Despite of the general consensus to the above definition of inclusion, there are a wide range of differences in the policies and practices of inclusive education in different countries.

Bangladesh with its birth committed to the nation the rights of basic education for all children which is clearly stated in the constitution, "The state shall adopt effective measures for the purpose of establishing a uniform, mass oriented and universal system of education and extending free and compulsory education to all children to such stage as may be determined by law". Acknowledging primary education as a national responsibility of the state and recognizing the fundamental rights of the people education steered in a new era in Bangladesh. Since its independence, Bangladesh has undertaken many initiatives to improve its education in line with its national development objectives.

One of the challenges facing education system in Bangladesh is provision of education, as a constitutional right, to those learners who have been marginalized and could not be accommodated by the learning institutions because of different disabilities. Even the majority of those who are accommodated cannot fully participate in learning activities meaningfully in their classroom. These are the students whose needs are special that some modifications within teaching-learning process are a precondition in order to enable them to fully participate and benefit from the process of inclusive education.

An inclusive classroom is one which includes students with and without special needs. The students are not judged on race, gender, disability or any other differences. So, the teacher's goal is to create lessons that can be adapted to different learning styles and needs. The challenge of most inclusive environments is meeting the diverse needs of all learners according to their strengths, ability levels, and needs, without separating students homogeneously according to 
their ability levels.

This study will emphasize on the evidence-based teaching strategies that have been found to be very effective and significant particularly for inclusive classroom. Evidence-based teaching practices movement began in pedagogy in the mid-nineties. Evidence-based teaching strategies are clearly specified teaching strategies that have been shown in controlled research to be effective in bringing about desired outcomes in a delineated population of learners. This is the integration of professional expertise, learners' ability and the best research evidence into the decision making process for teaching-learning in the classroom. For teaching-learning process in inclusive classrooms, evidence-based teaching strategies can play a vital role for quality learning especially for the students with disabilities.

\section{Figure 1 : Components of evidence-based teaching practice}

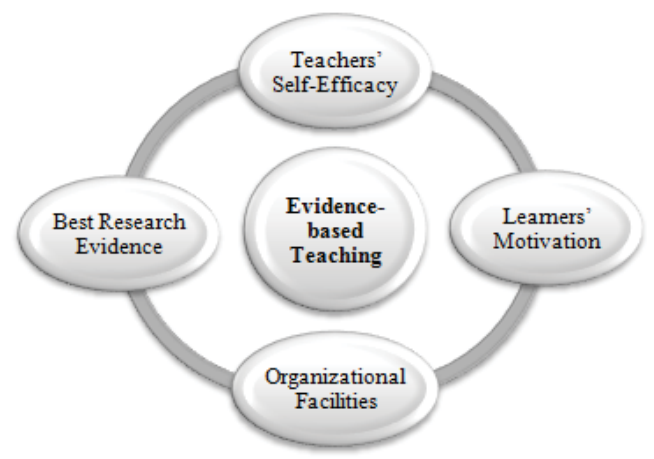

Source: Adapted from David Sackett's Model, 1996

By applying as many as possible of the above criteria, David Mitchell (2008) arrived at a total number of 18 evidencebased teaching strategies, some of which included several sub-strategies. Although they are illustrated with reference to students with disabilities in inclusive classroom, almost all the strategies have general applicability.

Mitchell (2009) emphasised that he was not arguing for a single strategy or blueprint that all teachers should use. Rather, he felt that the most effective programmes are those that incorporate a variety of best practices. His strong advice was that educators should develop a repertoire of such strategies nested within their own philosophy, personality, craft knowledge, professional wisdom, and, above all, their knowledge of the characteristics and needs of their students and their knowledge of local circumstances.

The 18 strategies used in this study are presented below:

$\begin{array}{ll}\text { 1. } & \text { Cooperative Group Teaching } \\ \text { 2. } & \text { Peer Tutoring } \\ \text { 3. } & \text { Review and Practice } \\ \text { 4. } & \text { Formative Assessment } \\ \text { 5. } & \text { Feedback } \\ \text { 6. } & \text { Cognitive Strategy Instruction } \\ \text { 7. } & \text { Self-regulated Learning } \\ \text { 8. } & \text { Memory Strategies } \\ \text { 9. } & \text { Reciprocal Teaching }\end{array}$
10. Behavioural Approaches
11. Social Skills Instruction
12. Motivating Class Environment
13. Adequate Active Learning Time
14. Assistive Technology
15. Parental Involvement
16. Phonological Processing
17. Optimal Physical Environment
18. Combined Strategies

9. Reciprocal Teaching

This study aimed at achieving the following objective:

- To identify teaching strategies that Bangladeshi teachers practice in teaching students with disabilities in mainstream primary classroom

And, this has been guided by the following research question:

- What types of teaching strategies do the Bangladeshi teachers practice (most/ sometimes/ less) in teaching students with disabilities in mainstream primary classroom? 


\section{Status of Inclusion in Primary Education in Bangladesh}

In the recent years Bangladesh has achieved a remarkable progress in access to basic education. Bangladesh has undertaken various measures with regard to Education for All (EFA). As a result, the net primary enrolment rate has been increased from 65\% in 1997 to 91\% in 2007 (Jahangir 2008). More remarkably, Bangladesh has already achieved one of the Millennium Development Goals (MDGs) of gender parity in primary and secondary education (Nasreen and Tait, 2007). Also, the enrollment ratio of students with disabilities in mainstream primary education is increasing year by year (Annual Sector Performance Report, Directorate of Primary Education, 2010). But still there are a lot of shortfalls and challenges in implementation mechanism for inclusion of students with disabilities and promotion of quality education in mainstream primary education in contemporary education system in Bangladesh.

Since 2005, the number of enrolled male and female students with disabilities in primary schools is increasing rapidly. As figure 2 shows, the number of students with disabilities enrolled in GPS and RNGPS increased by $70 \%$ between 2005 and 2010. Of the 77,500 students enrolled in 2010, about $25 \%$ belong to four sub-categories (physical disabilities, visual impairment, hearing impairment and mental retardation). The results exceeded by far the annual growth rate target of $5 \%$ in the enrollment of students with disabilities (Annual Sector Performance Report, Directorate of Primary Education, 2010).

Figure 2 : Number of enrolled students with disabilities in primary schools (2005-2010)

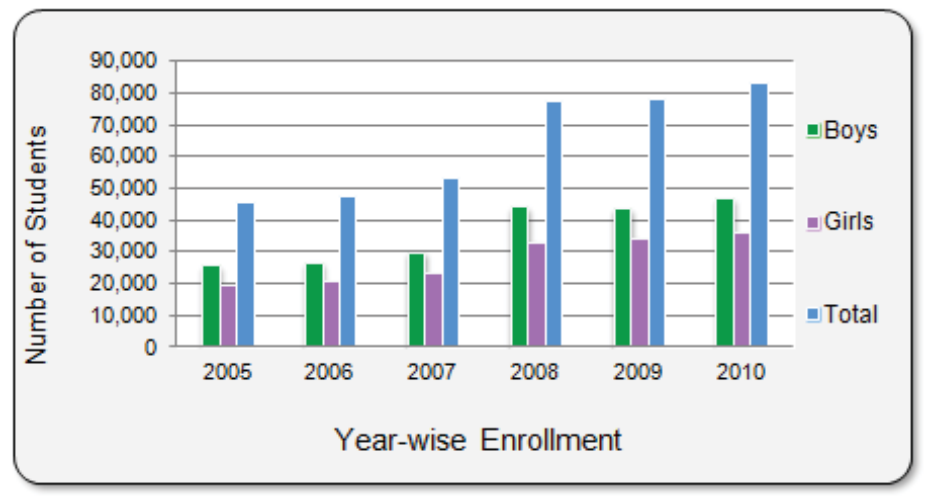

Source : ASPR 2011, Directorate of Primary Education, GoB

\section{Review of Literature}

Inclusive education can only be successful of teachers are adroit to adapt various teaching strategies to meet diverse educational needs if students in regular classroom (Horne 1983, Malone \& Long 2001). Differentiated instruction has been identified as effective teaching method that can address this issue for a variety of students in inclusive classroom (Salend 2001, Tomlinson 1999). Gartin, Murdick, Imbeau and Perner (2002) emphasized on planning of instruction using different strategies that address students' strengths, interests, skills, and readiness in flexible learning environments. It is important to study teachers' skills and practices in the classroom with integrated students with special needs (Walther Thomas et al. 2000). Schumm (1994) concluded that teachers who have been effective in working with mainstreamed students with learning disabilities report moderate to high agreement with the beliefs, skills and practices. Friend \& Bursuck (2002), Mastropieri and Scruggs (2000), Salend (2001) and Tomlinson (1995) greatly emphasized on the role of instructional adaptation in inclusive setting as an indispensable means for accommodating the needs of students with disabilities. The inclusive educators are required to be psychologically and practically prepared to take on the dynamic role in inclusive classroom (Mullen, 2001). To be an effective teacher in inclusive setting, a teacher must be patient, caring, creative, respectful to the students and skillful to organize the classroom (Murphy, Delli \& Edwards, 2004). Successful teachers challenge students' abilities by setting good quality tasks, providing students with opportunity to choose their tasks, variating teaching strategies that contribute to student learning (Ainscow, 1991). 


\section{Methodology}

\subsection{Sample}

A total number of 114 teachers from 37 primary schools located in four southern districts (Bagerhat-12, Jessore-9, Khulna-8, Satkhira-8 schools) of Bangladesh who have been teaching classroom consist of students with disabilities for minimum one year. So, it can be said that the sample teachers were selected purposively for this study.

\subsection{Instrumentation}

A three point likert type questionnaire was adapted to examine teachers' teaching practices in inclusive classroom. According to the list finalized by David Mitchell (2009) the questionnaire has been constructed. Almost all strategies are present in the statements of questionnaire. The questionnaire consisted of 18 statements and each statement was categorized into 'less practiced', 'sometimes practiced', and 'most practiced'. The participant teachers were instructed to put a tick mark $(\checkmark)$ a category among three that best describes their teaching practices in their classroom against each statement.

\subsection{Procedure of Data Collection}

After finalization of likert-type questionnaire, it was distributed to participant teachers. Participants were asked to tick by selecting what they do on each of the eighteen statements that included teaching strategies on instructional objectives, classroom arrangement, peer involvement etc. Moreover, necessary documents on primary education and teaching strategies were reviewed from the viewpoint of inclusive education.

\subsection{Data Analysis}

The study is descriptive in nature. The design is non-experimental soliciting information from teachers on the instructional strategies they use in teaching inclusive classroom in the primary schools. Descriptive statistics was employed to see the percentage of use of strategies by teachers. In data analysis, the number of frequency of responses was counted first for each statement/strategy. For each statement, how many responses came at 'rarely/less frequently' category, how many at 'sometimes' category and how many came at 'most often/ most frequently' category were counted and calculated into percentage. The percentages of responses for each category were displayed through a bar chart. The percentages of responses were taken into consideration only when it was above $50 \%$.

\section{Results and Discussion}

\subsection{Most frequently practiced teaching strategies}

According to table 1 titled most frequently practiced teaching strategies, there were four strategies (statement 1, 3, 9 and 15) found to be used most often. Within this category, statement no. 3 that is about physical arrangement of classroom was chosen mostly used strategy (76\% response). Actually these strategies do have much significance to create not only an inclusive classroom but also an effective classroom for participation of all students in general education setting.

Table 1: Most practiced teaching strategies in Bangladeshi classroom

\begin{tabular}{clcccccccc}
\hline \multirow{2}{*}{ No. } & Statements & $N$ & \multicolumn{2}{c}{ Rarely } & \multicolumn{2}{c}{ Sometimes } & \multicolumn{2}{c}{ Most Often } \\
\cline { 3 - 9 } & & Freq. & $\%$ & Freq. & $\%$ & Freq. & $\%$ \\
\hline 3 & $\begin{array}{l}\text { I ensure that classroom is spacious to } \\
\text { allow for free movement. }\end{array}$ & 114 & 8 & $7 \%$ & 19 & $17 \%$ & 87 & $76 \%$ \\
\hline 9 & $\begin{array}{l}\text { I ensure that questions are fair and evenly } \\
\text { distributed to allow students to contribute }\end{array}$ & 113 & 10 & $9 \%$ & 24 & $21 \%$ & 79 & $70 \%$ \\
\hline
\end{tabular}




\begin{tabular}{|c|c|c|c|c|c|c|c|c|}
\hline & to lessons. & & & & & & & \\
\hline 1 & $\begin{array}{l}\text { I try to arrange my classroom to } \\
\text { encourage participation. }\end{array}$ & 114 & 16 & $14 \%$ & 26 & $23 \%$ & 72 & $63 \%$ \\
\hline 15 & $\begin{array}{l}\text { I constantly monitor all my students } \\
\text { including those with disability while they } \\
\text { do class work }\end{array}$ & 112 & 10 & $9 \%$ & 33 & $29 \%$ & 69 & $62 \%$ \\
\hline
\end{tabular}

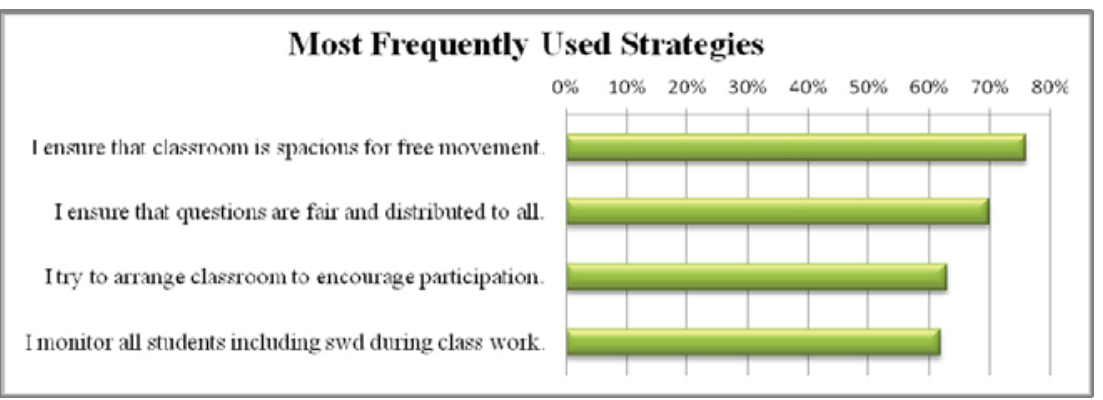

Figure 3: Percentage of most frequently practiced teaching strategies

\subsection{Teaching strategies practiced sometimes}

From the table 2, this is revealed that there were seven strategies out of 18 (statement no. 2, 5, 6, 8, 10, 13 and 17) found to be practiced sometimes. $71 \%$ responses came for the statement no. 5 which is related to team-teaching approach. These teaching strategies are somehow important for teaching students with disabilities in ordinary classrooms. However, they have general applicability also. Statement no. 6 is quite relevant with effective inclusive teaching strategy that is about peer tutoring, but the percentage of response is only $51 \%$.

Table 2 : Teaching strategies practiced sometimes in Bangladeshi classroom

\begin{tabular}{clccccccc}
\hline \multirow{2}{*}{ No. } & Statements & \multirow{2}{*}{$N$} & \multicolumn{2}{c}{ Rarely } & \multicolumn{2}{c}{ Sometimes } & \multicolumn{2}{c}{ Most Often } \\
\cline { 4 - 9 } & & Freq. & $\%$ & Freq. & $\%$ & Freq. & $\%$ \\
\hline 5 & $\begin{array}{l}\text { I select instructional materials that make it } \\
\text { possible for all to learn. }\end{array}$ & 114 & 13 & $11 \%$ & 81 & $71 \%$ & 20 & $18 \%$ \\
\hline 8 & $\begin{array}{l}\text { I give sufficient time to all students to } \\
\text { complete classwork or homework }\end{array}$ & 112 & 11 & $10 \%$ & 79 & $70 \%$ & 22 & $20 \%$ \\
\hline 13 & $\begin{array}{l}\text { I give individual attention to students who } \\
\text { need extra support }\end{array}$ & 113 & 17 & $15 \%$ & 75 & $66 \%$ & 21 & $19 \%$ \\
\hline 2 & $\begin{array}{l}\text { I set instructional objective to overall } \\
\text { students including those with disabilities }\end{array}$ & 113 & 18 & $16 \%$ & 70 & $62 \%$ & 25 & $22 \%$ \\
\hline 10 & $\begin{array}{l}\text { I keep daily records of the progress } \\
\text { students make in class. }\end{array}$ & 111 & 9 & $8 \%$ & 69 & $62 \%$ & 33 & $30 \%$ \\
\hline 17 & $\begin{array}{l}\text { I mix up the students when they are } \\
\text { performing assignment. }\end{array}$ & 114 & 23 & $20 \%$ & 66 & $58 \%$ & 25 & $22 \%$ \\
\hline 6 & I ask students to help each other. & 113 & 20 & $18 \%$ & 58 & $51 \%$ & 35 & $31 \%$ \\
\hline
\end{tabular}




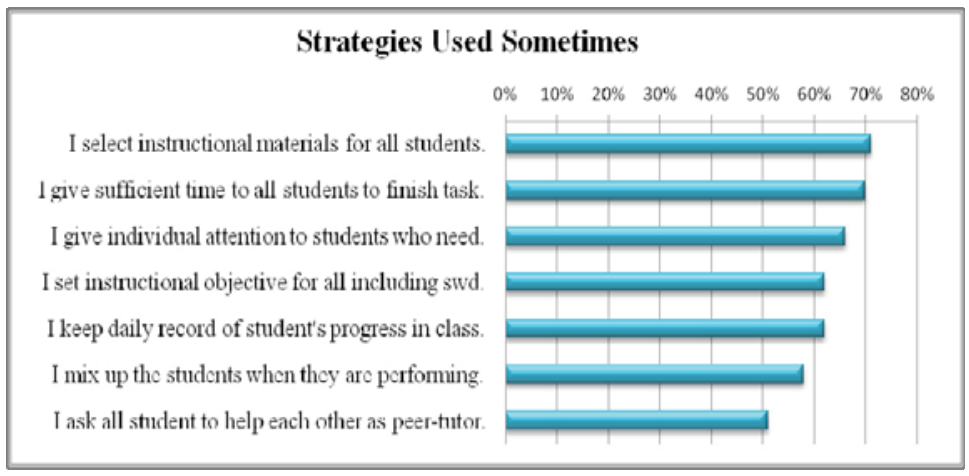

Figure 4 : Percentage of teaching strategies practiced sometimes

\subsection{Less frequently practiced teaching strategies}

Out of 18 strategies seven (statement no. 4, 7, 11, 12, 14, 16 and 18) were found to be practiced less frequently in inclusive classroom. But, it can be noted here that these less frequently practiced strategies are so effective for inclusive teaching rather than other strategies. One of the most effective strategies for students with disabilities is designing individualized education program/plan (IEP) (statement no. 16) that was found in the list of less-frequently practiced strategies and $78 \%$ responses came for this strategy as rarely practiced. Statement no. 14 that is associated with collaboration with other stakeholders was found to be least practiced (84\% responses as rarely used) and $68 \%$ responses came for statement no. 18 that is about accommodation for teaching-learning. Moreover, for statement no. 11, related to active participation of all, $76 \%$ responses were reported that teachers seldom move to a new section or unit after all learners understand it and can perform what they have learned.

Table 3 : Less frequently practiced teaching strategies

\begin{tabular}{clccccccc}
\hline \multirow{2}{*}{ No. } & Statements & N & \multicolumn{2}{c}{ Rarely } & Sometimes & \multicolumn{2}{c}{ Most Often } \\
\cline { 5 - 8 } & & & Freq. & $\%$ & Freq. & $\%$ & Freq. & $\%$ \\
\hline 14 & $\begin{array}{l}\text { I approach consultant for advice when I do not } \\
\text { know how to make all learner in classroom } \\
\text { learn }\end{array}$ & 114 & 96 & $84 \%$ & 14 & $12 \%$ & 4 & $4 \%$ \\
\hline 16 & $\begin{array}{l}\text { I design individualized education program (IEP) } \\
\text { for student with disability }\end{array}$ & 114 & 89 & $78 \%$ & 19 & $17 \%$ & 6 & $5 \%$ \\
\hline 11 & $\begin{array}{l}\text { I move to a new unit when all learners have } \\
\text { understood and can perform what they learnt }\end{array}$ & 114 & 87 & $76 \%$ & 19 & $17 \%$ & 8 & $7 \%$ \\
\hline 4 & $\begin{array}{l}\text { I select learning tasks that students with } \\
\text { disabilities can perform }\end{array}$ & 113 & 81 & $71 \%$ & 20 & $18 \%$ & 12 & $11 \%$ \\
\hline 18 & $\begin{array}{l}\text { I allow learners with difficulties in writing chance } \\
\text { to answer questions by saying it orally or } \\
\text { verbally }\end{array}$ & 114 & 77 & $68 \%$ & 22 & $19 \%$ & 15 & $13 \%$ \\
\hline 7 & $\begin{array}{l}\text { I let students with disabilities work at different } \\
\text { activities when assignment is given. }\end{array}$ & 112 & 65 & $58 \%$ & 26 & $23 \%$ & 21 & $19 \%$ \\
\hline 12 & $\begin{array}{l}\text { I allow students with disabilities to engage in } \\
\text { certain activities elsewhere in classroom. }\end{array}$ & 113 & 58 & $51 \%$ & 34 & $30 \%$ & 21 & $19 \%$ \\
\hline
\end{tabular}




\section{Less Frequently Used Strategies}

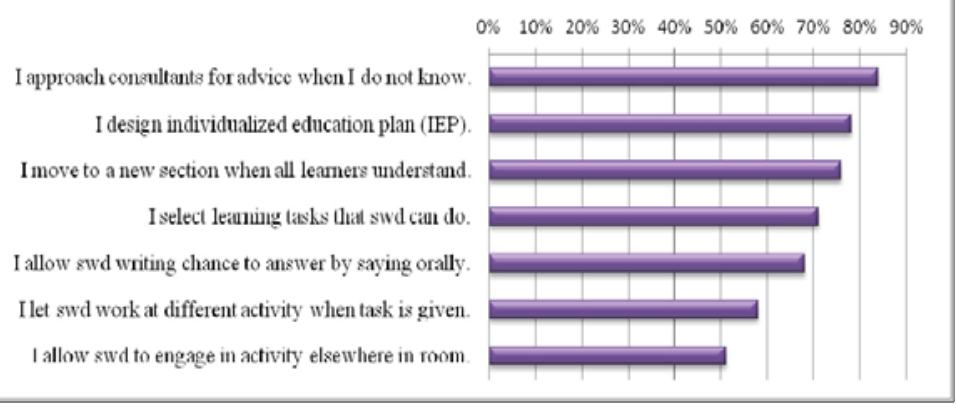

Figure 5 : Percentage of less frequently practiced teaching strategies

\section{Conclusion}

Selection and practices of teaching strategies for students with disabilities in inclusive classroom are very significant in terms of effective teaching-learning for students. Understanding and practicing specific and appropriate strategies will allow teachers to improve students' achievement levels, provide a wider range of instructional alternatives, and promote diversified learning methods for any degree of student ability. It is a teacher's awareness of the different tools and resources that build a bridge across educational achievement gaps. Becoming experts on these useful strategies is a concrete way to ensure that "all students have a better chance to learn, excel, and live out their dreams".

Bangladesh has been implementing inclusive education in its ordinary primary schools for last decade. Nevertheless, the teachers, i.e., main implementers are not prepared well to adjust with this phenomenon. They are accountable for proper implementation of it, but not aware of using special techniques or strategies and how to facilitate the teaching-learning process within the inclusive environment.

Although the list of teaching strategies are illustrated with reference to students with disabilities, almost all the strategies have general applicability, but no efficient use in the classrooms in Bangladesh. Through this study, it can be recommended that some effective and significant teaching strategies should be incorporated in primary level training manuals or any type of training materials. In addition, the practice of these strategies should be simulated during training course in order to apply in the real classroom situation. There are many teachers who have been trained on teaching in inclusive setting cannot practice the effective strategies or techniques due to some obstacles existing in Bangladeshi education structure. Unquestionably, successful inclusion cannot be achieved unless effective strategies are fully practiced in classroom teaching-learning process.

\section{References}

Ackerman, P., Thormann, M. \& Huq, S. (2005). Assessment of educational needs of disabled children in Bangladesh, USAid, USA. Ahuja, A. \& Ibrahim, M. D. (2006). An Assessment of inclusive education in Bangladesh. UNESCO-Dhaka.

Ainscow, M. (2005). Developing inclusive education systems: What are the levers for change? Journal of Educational Change, $6,109-$ 124.

Ainscow, M. (1994). Special needs in the classroom: A teacher education guide, Jessica Kingley Publishers/ UNESCO Publishing.

Alton-Lee, A. (2003). Quality teaching for diverse students in school: Best evidence synthesis. Wellington, NZ: Ministry of Education.

Asim, D. (2010). Trends and issues of special needs education for students with developmental disorders in Japan. Journal of Learning Strategy Intervention, 1(2), 41-50.

Asim, D. (2011). Inclusion of students with disabilities in mainstream primary education of Bangladesh. Journal of International Development and Cooperation, 17(2), 1-10.

Asim, D. (2012). In-service teachers' perceptions toward inclusion of students with disabilities in mainstream primary classroom: A case of some selected primary schools in southern Bangladesh. Journal of International Development and Cooperation, 18 (3), 149 157.

Asim, D. \& Ochiai, T. (2012). Effectiveness of C-in-Ed course for inclusive education: Viewpoint of in- service primary teachers in southern Bangladesh. Journal for Inclusive Education, 2 (10), 2-14.

Asim, D. \& Ochiai, T. (2012). Examining primary teachers' views on teacher education for teaching students with disabilities in inclusive classrooms in Bangladesh, International Journal of Research in Social Sciences, 2(4), 379-393. 
Avramidis, E. \& Norwich, B. (2002). Teachers' attitudes towards integration/ inclusion: A review of the literature. Journal of Special Needs Education, 17(2), 129-147.

Bain, A., Lancaster, J., Zundans, L. \& Parkes, R. J. (2009). Embedding evidence-based practice in pre-service teacher preparation. Teacher Education and Special Education, 32 (3), 215-225.

Corbett, J. (2001). Supportive inclusive education: a connective pedagogy. New York: Routledge.

Davis, P. \& Florian, L. (2004). Teaching strategies and approaches for pupils with special educational needs: A scoping study. London: DfES.

Emmanuel, K. G. (2011). Teachers' use of instructional strategies in primary schools in Ghana: implication to inclusive education. Education Research Journal, 1(3), 46-52.

Exley, S. (2003). Effectiveness of teaching strategies for students with dyslexia based on preferred learning styles. British Journal of Special Education, 30(4), 213-219.

Florian, L. (2009). Preparing teachers to work in 'schools for all'. Teaching and Teacher Education, 25 (4), 533-534.

Forlin, C. (ed.) (2010). Teacher education for inclusion : changing paradigms and innovative approaches. London: Routledge.

Golder, G., Norwich, B. \& Bayliss, P. (2005). Preparing teachers to teach pupils with special educational needs in more inclusive schools: evaluating a PGCE development. British Journal of Special Education, 32 (2), 92-99.

Gould, A. \& Vaughn, S. (2000). Planning for the inclusive classroom: meeting the needs of diverse classrooms. Catholic Education, 3 (3), 363-374

Hadadian, A. and Chiang, L. (2007). Special education training and pre-service teachers. International Journal of Special Education 22 (1), 103-106.

Jennifer, K. \& Pat, M. (2002).Including students with developmental disabilities in general education classrooms: educational benefits. International Journal of Special Education, 17 (2), 14-24.

JICA (2002). Country Profile on Disability : People's Republic of Bangladesh.

Jordan, A., Schwartz, E. \& Richmond, D. (2009). Preparing teachers for inclusive classrooms. Teaching and Teacher Education, 25 (4), 535-542.

Jung, W. S. (2007). Preservice teacher training for successful inclusion. Education, 128 (1), 106-113.

Kim, J. (2011). Influence of teacher preparation programs on pre-service teachers' attitudes toward inclusion. International Journal of Inclusive Education, 15 (3), 355-377.

Lewis, A. \& Norwich, B. (eds.) (2005). Special teaching for special children. Maidenhead, Oxford University Press.

Lise, V. (2003). From integration to inclusion: focusing global trends and changes in the Western Europe. European Journal of Special Needs Education, 18 (1), 17-35.

Loreman, T., Deppeler, J. \& Harvey, D. (2005). Inclusive Education: A practical guide to supporting diversity in the classroom. Sydney: Allen and Unwin.

Meijer, C. J. W. (ed.) (2003). Inclusive education and classroom practice. Odense, Denmark: European Agency for Development in Special Needs Education.

Mock, R. \& Kauffman, J. (2002). Preparing teachers for full inclusion: Is it possible? The Teacher Educator, 37(3), 202-215.

MoE (2010). The national education policy 2010. Dhaka: The Government of Bangladesh.

MopME (2008). School survey report-2007, Second Primary Education Development Program, Directorate of Primary Education, Dhaka.

MoPME (2009), Bangladesh primary education annual sector performance report-2010, Second Primary Education Development Program, DPE.

Nevin, A., Thousand, J. \& Villa, R. (2009). Collaborative teaching for teacher educators -What does the research say? Teaching and Teacher Education, 25 (40), 569-574.

OECD (1995). Integrating students with special needs into mainstream schools, OECD Publication, France.

Salend, S. J. (1998). Effective mainstreaming: Creating inclusive classrooms (3rd. ed.). Columbus, OH: Merrill/Prentice Hall.

Salend, S. J. (2001). Creating Inclusive Classrooms: Effective and reflective practices. $4^{\text {th }}$ edition, Upper Saddler River, NJ: Merrill Prentice Hall.

Stakes, R. \& Hornby, G. (2000). Meeting special needs in mainstream schools: a practical guide for teachers, (2nd ed.), London, David Fulton.

UNESCO (2009). Inclusive education: The way of the future. Final Report of the International Conference of Edicaton (48 Paris: UNESCO.

World Bank (2008). EFA in Bangladesh. Bangladesh Development Series, Paper No-24. 